\title{
SAFETY TOWARDS TRICHOGRAMMA CHILONIS ISHII IN LABORATORY AND PHYTOTOXICITY OF SELECTED BOTANICALS
}

\section{T. SELVAMUTHUKUMARAN \& K. JAYAKUMAR}

Department of Entomology, Faculty of Agriculture, Annamalai University, Annamalainagar, Tamil Nadu, India

ABSTRACT
Brinjal (Solanum melongena L.; Solanacae) is one of the important vegetable crops of India. Productivity in
India is decreased by many major insect pests. Insecticides are popular control methods. They are harmful to natural
enemies. Hence, safety of selected indigenous botanical preparations like Neem oil (0.5 \%), Neem seed kernel extract
$(5 \%)$, Acorus calamus extract (50\%) and five leaf extract (10\%) towards Trichogramma chilonis Ishii was studied. It
clearly indicated the superior safety profile of all the selected botanical preparations. The total absence of adult
emergence in Chlorpyriphos (100\%) indicated its ill effect on natural enemies. Studies on phytotoxicty revealed that
Acorus calamus extract and Chlorpyriphos in double the recommended dose exhibited the phytotoxic symptoms.
KEYWORDS: Brinjal, Indigenous Botanical Preparations, Natural Enemies, Safety Test, Phytotoxicity

Received: Jul 5, 2017; Accepted: Aug 01, 2017; Published: Aug 18, 2017; Paper Id.: IJASRAUG201799

\section{INTRODUCTION}

Brinjal (Solanum melongena L.; Solanacae) known also as "egg plant" or "aubergine", is one of the important vegetable crops of India. It is highly nutritive and rich in minerals like Iron, Phosphorous, Calcium and Vitamins (Singh et al., 1963). Productivity of brinjal in India is 19.10 tonnes/ha as against a world average of 25 tonnes/ha. One of the main reasons for such decreased productivity is incidence of major insect pests like Shoot and Fruit borer Leucinodes orbonalis Guenee (Pyraustidae: Lepidoptera), Epilachna beetle Epilachna vigintioctopunctata Fab. (Coleoptera: Coccinellidae), Whitefly Bemisia tabaci Gennadius (Aleyrodidae: Hemiptera) and Mealybug Coccidohystrix insolita Green (Pseudococcidae: Hemiptera). Managing these pests using insecticides is the most common and popular method among farming community. According to Alam et al., (2011) over 95 percent of farmers in Gujarat applied more than 40 sprays per season and 86 percent in Uttar Pradesh sprayed their crop two or three times a week. These alarming trends in usage of insecticides proved to be harmful to natural enemies. These facts stressed the importance of eco-friendly pest management tools as like botanicals. Hence, the present study evaluated the safety of indigenous botanical preparations like neem oil, Neem Seed Kernel Extract, Acorus calamus extract and five leaf extract along with a standard insecticide check Chlorpyriphos $20 \mathrm{EC}$ in the laboratory towards chilonis Ishii, a minute Hymenopteran egg parasitoid, which play a vital role in pest management (Singh and Jalali, 1994). Further, phytotoxicity evaluation was also carried out under green house condition. 


\section{METHODS}

\section{Evaluation of Safety of Selected Indigenous Botanical Preparations on Egg Parasitoid, Trichogramma Chilonis Ishii in Laboratory}

The safety bioassay was carried out as per Halappa et al. (2013) with modifications. The parasitized egg cards (16 cm x $32 \mathrm{~cm}$ ) were purchased from Kamaraj Krishi Vigyan Kendra, Pondicherry. Each egg cards were sprayed with $2.5 \mathrm{ml}$ various selected indigenous botanical preparations and insecticide at field recommended doses (Neem oil - 0.5\%; NSKE $5 \%$; Acorus calamus extract - $50 \%$; Five leaf extract - $10 \%$ and Chlorpyriphos 20 EC - 0.001 \%) using the Potter's spray tower. Distilled water was used in the untreated check. The treated egg cards were shade dried for 10 min. After complete drying, three $7 \times 2 \mathrm{~cm}$ cards, representing three replications were cut carefully from the treated cards and kept in test tubes $(15 \mathrm{~cm} \times 2.5 \mathrm{~cm})$. Using zoom stereomicroscope (Model: STEMI DV4; CARL ZEISS) number of emerged parasitoids per sq. cm. was recorded after 12, 24 and $48 \mathrm{~h}$. in each treatment. Per cent emergence was worked out using the formula:

Number of Wasps Emerged

Per cent of Emergence $=\longrightarrow \times 100$

Total Number of Eggs sq cm

\section{Phytotoxicity of Selected Botanical Preparations on Brinjal}

A Green house experiment was carried out to study the phytotoxicity level of selected indigenous botanical preparations at recommended dose and twice the recommended dose. Neem oil (0.5\% and 1.0\%), Neem seed kernel extract (5\% and 10\%), Acorus calamus extract (50\% and 100\%), five leaf extract (10\% and 20\%) and Chlorpyriphos (0.001 and $0.002 \%)$ were sprayed on ten selected plants using hand sprayer. The phytotoxicity symptoms like necrosis, epinasty, hyponasty and leaf tip injury were observed on $1^{\text {st }}, 3^{\text {rd }}, 7^{\text {th }}$ and $10^{\text {th }}$ day after spraying. Per cent phytotoxicity was worked out and rated adopting 1-10 scale as described by Ramaraju et al., (1998).

\section{RESULTS AND DISCUSSIONS}

The per cent adult parasitoid emergence, noticed in each treatment, clearly revealed the superior safety profile of indigenous botanical preparations against natural enemies. The total absence of adult emergence (100\%) in Chlorpyriphos 20 EC indicated its ill effect on natural enemies. The emergence data recorded in botanical preparations indicated their safety towards non target organisms. Among them, five leaf extract reduced emergence maximum (27\%) followed by Neem seed kernal extract (19.3\%), Neem oil (16\%) and Acorus calamus (12\%), when compared with control (Table 1). These facts highlighted the importance of indigenous botanical preparations in ecology based pest management strategies. They imparted reduction in adult emergence to the tune of 12 to 27 per cent only. This finding was supported by Rao and Raghuraman (2005), who reported relative safety of neem and A. calamus. These facts highlighted the role of feeding mediated toxicity in botanical preparations, which never happened in T. chilonis bioassay. These findings underscored the compatibility among these pest management components.

The results of the phytotoxicity analysis tested at recommended and double the recommended dose revealed that there was no phtotoxicity in the indigenous botanical preparations at recommended dose. However, when tested at double the dose, Chlorpyriphos $(0.002 \%)$ with a rating of 3 (23\% phytotoxicity) and Acorus calamus extract (100\%) with rating 
of 2 (18\% phytotoxicity) showed signs of phytotoxicity. The phytotoxic symptoms exhibited in Acorus calamus extract at double the recommended dose $(100 \%)$ might be due to the increased concentration. The other indigenous botanical preparations namely Neem oil, Neem seed kernel extract and five leaves extract, showed nil phytotoxic symptoms as like untreated control (Table 2). Madiwalar and Shekharappa (2015) also revealed that NSKE and plant mixture extract caused nil phytotoxic symptoms even at four times the dose. The safety of other indigenous botanical preparations to brinjal crop makes their field utilization easier.

Table 1: Laboratory Evaluation of Selected Indigenous Botanical Preparations and Standard Insecticide on Trichogramma Chilonis Ishii Adult Emergence

\begin{tabular}{|c|c|c|c|}
\hline \multirow[t]{2}{*}{ Treatments } & \multicolumn{2}{|c|}{$\begin{array}{c}\text { Per cent Adult } \\
\text { Emergence* } \\
\text { (Hours After Treatment) }\end{array}$} & \multirow[t]{2}{*}{$\begin{array}{c}\% \text { Reduction in Adult } \\
\text { Emergence Over Control }\end{array}$} \\
\hline & 24 & 48 & \\
\hline Neem oil $(0.5 \%)$ & $\begin{array}{c}43.31 \\
(41.14) \mathrm{ab}\end{array}$ & $\begin{array}{c}79.64 \\
(63.63) \mathrm{b}\end{array}$ & 15.75 \\
\hline Neem Seed Kernel Extract (5 \%) & $\begin{array}{c}43.10 \\
(41.02) \mathrm{b} \\
\end{array}$ & $\begin{array}{c}76.29 \\
(61.19) \mathrm{b}\end{array}$ & 19.30 \\
\hline Acorus calamus extracts $(50 \%)$ & $\begin{array}{c}32.55 \\
(34.77) \mathrm{d}\end{array}$ & $\begin{array}{c}83.67 \\
(66.88) \mathrm{b}\end{array}$ & 11.52 \\
\hline Five leaves extract (10\%) & $\begin{array}{c}36.23 \\
(36.99) \mathrm{c}\end{array}$ & $\begin{array}{c}69.32 \\
(56.54) \mathrm{b}\end{array}$ & 26.67 \\
\hline Chlorpyriphos (1 ml / litre) & - & - & 100 \\
\hline Untreated check & $\begin{array}{c}45.00 \\
(42.11) \mathrm{a}\end{array}$ & $\begin{array}{c}94.53 \\
(76.48) \mathrm{a}\end{array}$ & - \\
\hline S.Ed & 0.44 & 4.82 & - \\
\hline $\mathrm{CD}$ & 0.97 & 10.62 & - \\
\hline
\end{tabular}

*Mean of three replications

Values in parentheses are arc sine transformed values

Values with different alphabets with in columns differ significantly

Table 2: Phytotoxicity Evaluation of Selected Indigenous Botanical Preparations and Standard Insecticide at Recommended and Double the Recommended Doses

\begin{tabular}{|l|c|l|l|}
\hline \multicolumn{1}{|c|}{ Treatment } & $\begin{array}{c}\% \\
\text { Phytotoxicity }\end{array}$ & Ranking & \multicolumn{1}{c|}{ Symptoms } \\
\hline Recommended Dose & 0 & 0 & - \\
\hline Neem oil $(0.5 \%)$ & 0 & 0 & - \\
\hline Neem Seed Kernel Extract (5\%) & 0 & 0 & - \\
\hline Acorus calamus extract (50 \%) & 0 & 0 & - \\
\hline Five leaves extract (10 \%) & 0 & 0 & - \\
\hline Chlorpyriphos 20\% EC (1 ml / litre) & 0 & 0 & - \\
\hline Double the Recommended Dose & 0 & 1 & - \\
\hline Neem oil (1\%) & 18 & 2 & Necrosis, scorching, epinasty and hyponasty \\
\hline Neem Seed Kernel Extract (10\%) & 7 & 1 & - \\
\hline Acorus calamus extract (100\%) & 23 & 3 & Necrosis, scorching, epinasty and hyponasty \\
\hline Five leaves extract (20 \%)
\end{tabular}

\section{CONCLUSIONS}

Though insecticides are popular control materials, they are harmful to natural enemies. This study was conducted to test the safety of selected indigenous botanical preparations as pesticides. Indeed, the insecticides are popular control methods. However, the results on 
the absence of adult emergence in Chlorpyriphos shows its ill effect on natural enemies, and studies on phytotoxicty with Acorus calamus extract and Chlorpyriphos doses indicate the formation of phytotoxic symptoms that need attention!

\section{REFERENCES}

1. Alam, M. M., M. Z. Mondal, D. K Paul, M. A. Samad, M. A. Mamun and M. A. Chowdhury. "Determination of Pesticide Residue (Cartap) in Brinjal” Proceedings of the Pakistan Academy of Sciences, (89-93) - 48(2). 2011.

2. Halappa, J. S. Awaknavar, D. Archana and B. Doddabasappa, "Safety of biopesticides and newer insecticides to egg parasitoid, Trichogramma chilonis Ishii (Trichorgammitidae: Hymenoptera) in laboratory”, Insect Environment, (119) - 2, 2013.

3. Madiwalar, N. P. and Shekharappa. "Studies on the phytotoxicity of botanicals and chemical insecticides in kharif sorghum" Karnataka J. Agric. Sci., (110-111) - 28(1). 2015.

4. Ramaraju, K., K. Rajamanickam and C. S. Sridharan, "Efficacy of insecticide and botanicals against pests of groundnut. Pestology”, (27 - 30) - 22(8), 1998.

5. Rao, N. S. and S. Raguraman. "Influence of neem based insecticides on egg parasitoid,Trichogramma chilonis and green lacewing predator, Chrysoperla carnea." Journal of Ecobiology, (437-443 ) - 17 (5). 2005.

6. Singh, S. P. and S. K. Jalali, “Trichogrammatids” Technical Bulletin, PDBC, Bangalore, (93), 1994.

7. Singh, S., S. Krishnakumar and S. L. Katyal, "Fruit culture in India", Indian Council of Agricultural Research, New Delhi, (412). 1963. 